\title{
Local Regulation on Homelessness and Beggars in Yogyakarta: Human Rights and Maqasid of Sharia Perspectives
}

\author{
Ahmad Syafii Rahman
}

Univeristas Cokroaminoto, Yogyakarta, Indonesia

Email: syafii.drrahman@gmail.com

Amir Mu'allim

Univeristas Islam Indonesia, Yogyakarta, Indonesia

Article History:

\begin{tabular}{|l|l|}
\hline Received: December 02, 2021 & Accepted: March 12, 2021 \\
\hline Revised: Februari 17, 2021 & \\
\hline
\end{tabular}

\begin{abstract}
The existence of vagrants and beggars as a sub-culture of poverty is a separate problem for the government and the people of Yogyakarta in general. This research was conducted to examine and analyze the effectiveness of the Yogyakarta City Government Regional Regulation No. 1 of 2014 concerning the handling of homeless and human rights beggars in the review of maqasid shari'ah and seeks to find the crucial factors that influence the effectiveness of the DIY city government regulation based on a human rights perspective. humans in the view of maqasid syari' ah. The facts in the field were collected using qualitative methods with a sociological normative juridical approach and technical analysis using analytical descriptions. The results of this study are the Role and Functions of the Social Service in tackling Homeless and Beggars in the Special Region of Yogyakarta which has been procedurally fulfilled based on the Yogyakarta Regional Regulation No. 1 of 2014, but conceptually has not been fully implemented in the DIY City Regional Regulation No. 1 of 2014. In the perspective of human rights, in terms of quantity, the regional regulation has guaranteed the fulfillment of the rights of the homeless and beggars, the implementation is in accordance with standard operational procedures in the field. According to the Maqāsid syari' ah perspective, the government's program to overcome sprawl has realized the maqāsid Syar'ah, namely the maintenance of religion (hifz dn), reason (hifz al-aql) maintenance of the soul (hifz al-Nafs) maintenance of offspring (hifz al-Nasl) maintenance of property ( hifzu al-mal)
\end{abstract}

Keywords: Local Regulation, Human Rights, Maqasid Syariah 


\begin{abstract}
Abstrak
Keberadaan Gelandangan dan Pengemis sebagai salah satu sub-kultur kemiskinan menjadi persoalan tersendiri bagi pemerintah dan masyarakat Yogyakarta pada umumnya. Penelitian ini dilakukan untuk mengkaji dan menganalisis efektivitas Perda Pemerintahan Kota Yogyakarta No.1 tahun 2014 tentang penanganan gelandangan dan pengemis hak asasi manusia dalam tinjauan maqasid syari'ah dan berupaya menemukan faktor-faktor krusial yang mempengaruhi jalannya efektivitas perda pemerintahan kota DIY berdasarkan perspektif hak asasi manusia dalam tinjauan maqāsid syarı̄’ah. Fakta-fakta dilapangan dikumpulkan dengan metode kualitatif dengan pendekatan yuridis normative sosiologis dan tektin analisisnya menggunakan deskriprif analitis. Hasil penelitian dari penelitian ini adalah Peran dan Fungsi Dinas Sosial dalam menanggulangi Gelandangan dan Pengemis di Daerah Istimewa Yogyakarta secara prosedural telah terpenuhi berdasarkan Peraturan Daerah Yogyakarta No 1 Tahun 2014, Namun secara Konseptual belum sepenuhnya terimplementasi di dalam Peraturan Daerah Kota DIY No 1 Tahun 2014. Dalam Perspektif Hak Asasi Manusia, secara kuantitas, Perda telah menjamin pemenuhan hak-hak gelandangan dan pengemis, secara implementasi telah sesuai dengan standar prosedur operasional dilapangan. Menurut Perspektif Maqāsid syarī’ah program pemerintah penanggulangan Gepeng telah merealisasikan maqāsid Syarīah yaitu pemeliharaan agama (ḥifz dīn), akal (hifẓ al-aql) pemeliharaan jiwa (hifz al-Nafs) pemeliharaan keturunan (hifẓ al-Nasl) pemeliharaan harta (hifzu al-māl)
\end{abstract}

Kata Kunci: Peraturan Daerah, Hak Asasi Manusia, Maqasid Syariah

\title{
INTRODUCTION
}

Like other provinces in Indonesia, Yogyakarta Special Province or Yogyakarta also faces the problem of poverty. There are many factors that influence poverty in Yogyakarta: education, health, productivity, minimum wages, inflation, and others. ${ }^{1}$ Several policies have been implemented but have not been able to significantly reduce the poverty rate. ${ }^{2}$ The policy that empirically has a significant

1 Khurri Niswati, 'Faktor-Faktor Yang Mempengaruhi Kemiskinan Di Daerah Istimewa Yogyakarta Tahun 2003-2011 [Factors Affecting Poverty in the Special Region of Yogyakarta in 2003-2011]', Eko-Regional: Jurnal Pembangunan Ekonomi Wilayah 9, no. 1 (2014): 82-89, https:// doi.org/10.20884/1.erjpe.2014.9.1.480.

2 Juli Panglima Saragih, 'Faktor Penyebab Dan Kebijakan Pemerintah Provinsi Daerah Istimewa Yogyakarta Menghapus Kemiskinan [Causes of Poverty and 
impact on poverty in Yogyakarta is government spending on education and health. Thus, improving the quality of human resources is an important part of efforts to alleviate poverty in Yogyakarta. ${ }^{3}$ Poverty is an unresolved problem for the government, the world, as well as Indonesia, which has fairly high levels as a developing country. This problem is often the focus of the government during development by providing various community programs, especially in urban areas.

Complex social problems require serious cooperation between the central and local governments, including provinces and regencies or cities. It is realization of general and social welfare as the government's obligation and the nation's goals as stated in the 1945 Indonesian Constitution. The constitution mandated the state to respect, protect, fulfill, and educate its citizens. ${ }^{4}$ However, improper poverty handling can lead to increasingly complex social welfare problems, as indicated by the number of people with social welfare problems. The homeless and beggars are some critical social welfare problems with negative impacts, leading to the introduction of various alleviation policies by the local governments. ${ }^{5}$

Yogyakarta Government Policy for Eradicating Poverty]', Jurnal Ekonomi Dan Studi Pembangunan 6, no. 2 (2014): 139-55.

3 Novita Ika Sari, 'Determinan Tingkat Kemiskinan Di Daerah Istimewa Yogyakarta Tahun 2007 - 2014 [Determinants of Poverty Levels in the Special Region of Yogyakarta in 2007 - 2014]', Economics Development Analysis Journal 7, no. 2 (2018): 12836, https:// doi.org/10.15294/edaj.v8i2.23411.

${ }^{4}$ Mia Kusuma Fitriana, 'Peranan Politik Hukum Dalam Pembentukan Peraturan Perundang-Undangan Di Indonesia Sebagai Sarana Mewujudkan Tujuan Negara (Role of Politics in Creation of Laws and Regulations in Indonesia as the Means of Realizing the Country's Goal)', Jurnal Legislasi Indonesia 12, no. 2 (2015): 1-27; Johannes Suhardjana, 'Supremasi Konstitusi Adalah Tujuan Negara [The Supremacy of the Constitution Is the Goal of the State]', Jurnal Dinamika Hukum 10, no. 3 (2010): 253-64, https:/ / doi.org/10.20884/1.jdh.2010.10.3.96.

5 Siti Raudah, 'Implementasi Peraturan Daerah Nomor 17 Tahun 2015 Tentang Penanggulangan Masalah Gelandangan Dan Pengemis (Gepeng) (Ttudy Kasus Di Kecamatan Amuntai Tengah Kabupaten Hulu Sungai Utara) [Implementation of 
Yogyakarta City was centre for many bussiness, culture, art, and education activities in Yogyakarta Special Province. Its status as city of education and city of culture implies fast growing of urbanization which lead to a more severe problem in homelessness and poverty. ${ }^{6}$ The Government of Yogyakarta has also made several specific regulations to address the problem of homeless people and beggars. One of them was the Province Regulation of Yogyakarta Special Province No. 12014 on Countermeasures of the Homeless and Beggars or Perda No. 1 2014. ${ }^{7}$ The countermeasures of the homeless people and beggars regulated in Perda No. 12014 includes various processes related to this issue. These countermeasures are through (a) preventive, (b) coercive, (c) rehabilitative, and (d) social reintegration efforts.

Several researchers have analyzed Perda No. 12014 from various aspects with the results as described below. This regional regulation has a coercive strategy, in the form of criminalizing homeless people and beggars, as well as a preventive strategy that costs a lot of budget. ${ }^{8}$ From the aspect of criminal law, the procedure

Regional Regulation Number 17 Year 2015 on Efforts to Overcome Problems of Homeless and Beggars (Case Study in Amuntai Tengah Sub-District Hulu Sungai Utara)]', Jurnal PubBis 3, no. 1 (2019): 10-19; M. Zain Yaumil Akbar and Sulistyowati, 'Peran Pemerintah Kabupaten Brebes Dalam Menanggulangi Penyandang Masalah Kesejahteraan Sosial (PMKS) Pada Gelandangan Dan Pengemis (Studi Kasus Desa Grinting) [The Role of the Brebes Regency Government in Overcoming People with Social Welfare Problems on Homeless and Beggars (Case Study of Grinting Village)]', Journal of Politic and Government Studies 8, no. 03 (2019): 201-10.

6 Hendy Setiawan, 'Fenomena Gelandangan Pengemis Sebagai Dampak Disparitas Pembangunan Kawasan Urban dan Rural di Daerah Istimewa Yogyakarta [The Phenomenon of Homeless Beggars as the Impact of Disparity in Urban and Rural Development in Yogyakarta Special Province]', Moderat: Jurnal Ilmiah Ilmu Pemerintahan 6, no. 2 (2020): 361-75, https:/ / doi.org/10.25157/moderat.v6i2.3218.

7 Gubernur Daerah Istimewa Yogyakarta, 'Peraturan Daerah Daerah Istimewa Yogyakarta Nomor 1 Tahun 2014 Tentang Penanganan Gelandangan Dan Pengemis' (2014).

8 Jayyidan Falakhi Mawaza and Zaenuddin, 'Dilema Kebijakan Penanganan Gelandangan dan Pengemis di Yogyakarta (Studi Kasus Perda DIY No. 1 Tahun 2014) 
of handling homeless people and beggars is carried out as part of a broader, integralistic, and integrated policy. ${ }^{9}$ Coercive efforts through policing involving the Satpol PP in the last three years have not shown significant changes to the homeless and beggars. ${ }^{10}$ In general, the Rehabilitation and Preventive Strategies have been running well despite facing problems in the form of lack of human resources and lack of program innovation. In addition, community support is also lacking for the prohibition of giving money to beggars. ${ }^{11}$ Other researchers have also analyzed the implementation of the rehabilitation strategy ${ }^{12}$ and the importance of governmentprivate synergy ${ }^{13}$ in overcoming social problems in Yogyakarta.

[Policy Dilemma for Handling Homeless People and Beggers in Yogyakarta (Case Study of Perda No. 1 Year 2014)]', Spirit Publik: Jurnal Administrasi Publik 15, no. 2 (2020): 131-45, https://doi.org/10.20961/sp.v15i2.39754.

${ }_{9}$ Mufti Khakim and Egi Purnomo Aji, 'Penegakkan Hukum Peraturan Daerah Nomor 01 Tahun 2014 Tentang Penanganan Gelandangan Dan Pengemis Daerah Istimewa Yogyakarta [Law Enforcement of Regional Regulations Number 01 of 2014 Concerning the Handling of Homeless and Beggars in the Special Region of Yogyakarta]', Jurnal Citizenship: Media Publikasi Pendidikan Pancasila Dan $\begin{array}{lllll}\text { Kewarganegaraan no. } & \text { 26-37, }\end{array}$ https:/ / doi.org/10.12928/citizenship.v4i1.19906.

${ }^{10}$ Mutiaratih Larasati Jannati and Johannes Sutoyo, 'Hasil Dan Dampak Upaya Koersif Dalam Penegakan Peraturan Daerah Daerah Istimewa Yogyakarta Nomor 1 Tahun 2014 Tentang Penanganan Gelandangan Dan Pengemis [Results and Impact of Coercive Efforts in Enforcement of Yogyakarta Special Region Regulation Number 1 of 2014 Concerning Handling Homeless and Beggars]', Jurnal Kriminologi Indonesia 13, no. 1 (2018), http://journal.ui.ac.id/index.php/jki/article/view/9042.

11 Tiara Khairunnisa, Eko Priyo Purnomo, and Lubna Salsabila, 'Smart Urban Service: Upaya Rehabilitasi dan Preventif Pengemis dan Gelandangan Kota Yogyakarta [Smart Urban Service: Rehabilitation and Preventive Efforts for Beggars and Homeless in Yogyakarta City]', Moderat: Jurnal Ilmiah Ilmu Pemerintahan 6, no. 1 (2020): 29-42, https:// doi.org/10.25157/moderat.v6i1.3156.

12 Novie Purnia Putri and Munifatuz Zahro', 'Pemberdayaan Gelandangan Dan Pengemis Melalui Bimbingan Vokasi Di Balai Rehabilitasi Unit Bina Karya Yogyakarta [Empowerment of Homeless Households and Beggers Through Vocational Guidance at the Rehabilitation Center of the Bina Karya Unit, Yogyakarta]', EMPATI: Jurnal Ilmu Kesejahteraan Sosial 9, no. 1 (2020): 48-58, https:/ / doi.org/10.15408/empati.v9i1.16481.

13 Zainal Fadri, 'Upaya Penanggulangan Gelandangan Dan Pengemis (Gepeng) Sebagai Penyandang Masalah Kesejahteraan Sosial (PMKS) Di Yogyakarta [Efforts to 
Previous review indicates limitation of analysis of Perda 12014 on human rights and Islamic law perspectives. This current research was aimed to fill this gap by providing analysis based on human rights and maqasid of sharia perspectives.

\section{METHOD}

In general, this research does not use numbers and calculations so that it is included in the qualitative category. ${ }^{14}$ Furthermore, this research is included in the qualitative category because it is carried out by looking at real conditions in the field to observe phenomena and draw meaning from them. ${ }^{15}$ Data was collected using in-depth interviews and analysis of documents. Civil servants in the Yogyakarta City Government obliged to handle the implementation of Perda 12014 were main informants for this research. They were interviewed to explore various sides of information in the program process for the countermeasures of homeless people and beggars through the issuance of the government regulation.

\section{RESULTS AND DISCUSSION}

\section{Characteristics of Perda 12014 on Homeless People and Beggars}

Perda 12014 mandates some efforts to overcome the phenomenon of homeless people and beggars in Yogyakarta. These efforts along with its mechanism are explained below. Preventive

Manage Homeless Peopel and Beggars as Social Welfare Problems in Yogyakarta]', Komunitas 10, no. 1 (2019): 1-19, https:/ / doi.org/10.20414/komunitas.v10i1.1070.

14 Ian Dobinson and Francis Johns, 'Qualitative Legal Research', in Research Methods for Law, ed. Mike McConville and Wing Hong Chui (Edinburgh: Edinburgh University Press, 2007), 16-45.

15 Lisa Webley, 'Qualitative Approaches to Empirical Legal Research', in The Oxford Handbook of Empirical Legal Research, ed. Peter Cane and Herbert M. Kritzer (Oxford: Oxford University Press, 2010), 927-51, https://doi.org/10.1093/oxfordhb/9780199542475.013.0039. 
efforts included providing facilities, improving health quality, housing amenities, education, community counseling, supplying information through billboards in public places, social guidance, and assistance. ${ }^{16}$ Coercive efforts included activities such as a) order, a proactive effort to regulate and enforce the rule of law to create order, b) outreach, proactive efforts to reach zones that are often used as homes for the homeless and beggars; c) mental development in social protection house or RPS (Rumah Perlindungan Sosial); and d) handing homeless people and beggars to court for further law process. ${ }^{17}$ Rehabilitation efforts included activities such as a) motivation and psychosocial diagnosis, b) healthcare, c) vocational training and entrepreneurship development, d) spiritual mental guidance, e) physical guidance, f) social guidance and psychosocial counseling, g) accessibility services, h) social assistance, and i) guidance on resocialization. ${ }^{18}$ Social reintegration efforts included activities such as a) coordination with the local government of origin, b) family tracing, c) submission, and d) resocialization guidance. ${ }^{19}$

The Civil Service Police Unit or Satuan Polisi Pamong Praja (abbreviated Satpol PP) was authorized to take enforcement actions. Enforcement was conducted every two months through raids at crowded points or in the city center where the homeless and beggars were easily located. Enforcement was also conducted after reports of disturbing homeless persons and beggars from supervisors or the community. In 2016, there were 171 homeless people, higher than the 150 beggars estimated. A significant increase was observed in 2017,

16 Gubernur Daerah Istimewa Yogyakarta, Peraturan Daerah Daerah Istimewa Yogyakarta Nomor 1 Tahun 2014 Tentang Penanganan Gelandangan dan Pengemis Article 8.

17 Gubernur Daerah Istimewa Yogyakarta Article 9.

${ }^{18}$ Gubernur Daerah Istimewa Yogyakarta Article 10.

${ }^{19}$ Gubernur Daerah Istimewa Yogyakarta Article 13. 
as 235 homeless and 170 beggars were recorded, while 2020 documented a decrease to 197 and 147 , respectively. ${ }^{20}$

\section{Countermeasure Procedures}

An essential step in implementing this policy was following an appropriate procedure to achieve the expected goals. Office of Social Services cannot employ arbitrary policies that conflict with its field or procedure. Hence, the section must adhere to the procedures outlined in the government's regulation, which include 1) controlling, raiding, or outreaching to the homeless and beggars, synergized with supervisions by agencies or community elements. 2) Implementing social and mental rehabilitation by experts or practitioners that are members of guidance, social-mental, religious, citizenship, as well as physical and vocational health teams. 3) Conducting orientation and technical guidance to Assessment Camp officers. 4) Performing mental, social, and vocational rehabilitation continuously through a team of experts/practitioners, as well as 5) tracing and returning homeless persons and/or beggars outside Yogyakarta, 6) making referrals, and 7) repatriating such people to their areas of origin. ${ }^{21}$

The procedure for the countermeasures of the homeless and beggars, involving the initial stage, control, shelter at the Assessment Camp, and identification. Homeless and beggar children are separated and placed in appropriate camps for children, while nonpsychotic groups, street communities (e.g., punk children), and psychotic groups are referred to mental hospitals (RSJ). After receiving initial rehabilitation, further social rehabilitative and capacity-building processes are administered. The guidance flow is

20 Baried, Interview with Chief of Section of Social Rehabilitation for Socially Impaired and Drug Victims, 12 February 2020.

${ }^{21}$ Ismi, Interview with Office of Social Services, 13 February 2020. 
the process or stage of performing duties based on the procedures contained in Government Regulation Number 36 of 2017 concerning SOPs for Countermeasures of the Homeless and Beggars. ${ }^{22}$

The implementation of field realization comprises stages and procedures that correspond with the avoidance of unexpected technical errors. Rehabilitation is the initial stage performed at the assessment camp before repatriation and has entailed non-psychotic homeless and beggars as participants. About 136 homeless and beggars have received coaching, and 186 were referred to a mental hospital. The initial rehabilitation for coaching at the assessment camp involves 1) the development of interest in talent by psychologists, 2) hypnotherapy by a psychologist, 3) healthcare for psychotics by medical personnel, 4) physical training by practitioners, and 5) mental-based coaching by psychologists. ${ }^{23}$

\section{Socialization}

An important aspect at this stage is determining the policy to be implemented. Socialization determines the ability to increase the program's success, according to the goals and objectives. The countermeasures of the homeless and beggars in Yogyakarta are inseparable from the performance of local government agencies in performing their duties. The Office of Social Service uses various methods, such as electronic, print, and social media, as well as making signs at several busy intersections. Also, direct socialization is performed by informing the public of the importance of the policies established through Perda 12014 regarding the homeless and beggars. One of such important points is the refusal to give them

\footnotetext{
${ }^{22}$ Ismi.

${ }^{23}$ Ismi.
} 
money and the prohibition of homelessness and begging as professions. $^{24}$

\section{Fulfillment of the Rights}

The government is responsible for performing its political and democratic duties transparently and in a participatory manner. Consequently, three priority tasks must be fulfilled by the government in making policies, namely 1) ensuring individual and community security, 2) managing effective work programs that can satisfy public needs, and 3) fulfilling the goals of macroeconomic and social needs, according to the community's expectations. Generally, the government is built from various concepts based on responsibility, sense of worth, full participation, transparency (openness), effectiveness, and human rights. From a concept, it works at the micro (national), medium (regional), and macro (international) levels, involving a dialogical relationship through which specific principles are developed and implemented. ${ }^{25}$

The laws that suit social needs should be approached and analyzed as a social phenomenon, necessitating the study and placement of legal phenomena according to sociological analysis in its social context. ${ }^{26}$ Hence, the ideal concept for forming Regional Regulation Number 1 of 2014, which can fulfill the basic rights of homeless people and beggars, is seen from the philosophical, juridical, and sociological aspects. Therefore, the strategic efforts implemented to alleviate poverty can at least become the full power

${ }^{24}$ Baried, Interview with Chief of Section of Social Rehabilitation for Socially Impaired and Drug Victims.

${ }^{25}$ Baried.

26 Khudzaifah Dimyati and Kelik Wardiono, 'Dinamika Pemikiran Hukum: Orientasi Dan Karateristik Pemikiran Expertise Hukum Indonesia [The Dynamics of Legal Thought: Orientation and Characteristics of Indonesian Legal Expertise Thought]', Jurnal Ilmu Hukum 8, no. 2 (September 2005): 133-51. 
of the executive institution or regional government in implementing the next regulation. However, these efforts were not implemented properly due to several challenges and obstacles in the program.

\section{Analysis of Perda 12014 Effectiveness}

Two important factors in Maqāșid ash-Syarīah (achieving benefit) are used as the basic framework to measure the effectiveness of the Yogyakarta City Government Regional Regulation Number 1 of 2014 regarding the homeless and beggars. The first considered as positive side is implemented by maintaining activities that support the achievement of benefits. Conversely, the second acknowledged as negative aspect is performed by rejecting and avoiding all mafsadah (damage, destruction, or bad consequences that befall a person/group due to acts of law violations). Maqāsid ash-Syarī'ah is used as a guide or analysis of the effectiveness of this regulation, which should be one of the programs and efforts to focus on the basic needs of the homeless and beggars. Therefore, analyzing the Maqāșid ash-Syarī'ah approach aims to determine the effectiveness of the policy in the counter measuring the homeless and beggars in terms of human rights and according to their basic needs.

The Yogyakarta City Government Regional Regulation Number 1 of 2014 concerning Countermeasures of Homeless and Beggars was formed by considering that a) tackling the homeless and beggars is necessary to ensure they uphold the values of justice, order, and benefit, according to Pancasila and the 1945 Indonesian Constitution, and become dignified Yogyakarta citizens. b) Homeless people and beggars are social phenomena that endanger themselves, others, and public order, allowing them to become targets of exploitation and violence. c) The homeless and beggars are citizens that possess the same rights and obligations and deserve similar attention, hence comprehensive, integrated, directed, and sustainable 
countermeasures are necessary by involving various government and non-government elements to ensure they obtain decent lives.

Policies, laws, and regulations in counter measuring the homeless and beggars are contained in Articles 504 and 505 of the Criminal Code concerning Acts of Violation of Public Order. They are also present in Government Regulation Number 31 of 1980, strengthened by the Yogyakarta City Government Regional Regulation concerning Countermeasures of the Homeless and Beggars as part of a more operational policy that constitutes the legal basis for protection, social rehabilitation, and empowerment.

Several principles are used to countermeasure the homeless and beggars, namely a) Respect for dignity, self-respect, and self-esteem by avoiding arbitrary actions that degrade human dignity. b) Nondiscrimination by providing equal treatment based on gender, age, physical and mental condition, regional origin, ethnicity, religion, race, sexual, and political orientation. c) Non-violence by conducting these efforts humanely, promoting dialogue, motivation, and persuasion, and avoiding the use of violent means that endanger the safety of the homeless, beggars, other community members, and officials. d) Providing protection and shelter to these vulnerable groups. e) Realizing their welfare through the fulfillment of basic needs and other social services, and g) Empowerment by emphasizing efforts to develop their potentials, strengths, families, and environment, as well as advocacy actions to obtain their rights as citizens. $^{27}$

\section{Human Rights Overview of Perda 12014}

Table 1 described implementation of human rights concepts on Perda 1 2014. The data in the table showed that Perda 12014 has met

${ }^{27}$ Gubernur Daerah Istimewa Yogyakarta, Peraturan Daerah Daerah Istimewa Yogyakarta Nomor 1 Tahun 2014 Tentang Penanganan Gelandangan dan Pengemis. 
20 , or $83 \%$, of the 24 human rights parameters. Some points that were still unregulated such as social welfare insurance for the poor, community involvement in supervising the activities of social welfare providers, increasing institutional capacity and human resources in social welfare, and preserving the values of heroism, pioneering, and solidarity.

Table 1 Implementation of the Human Rights Concept in Yogyakarta City Regional Regulation Number 1 of 2014 concerning Countermeasures of the Homeless and Beggars

\begin{tabular}{|c|c|c|}
\hline Human Rights Concept & $\begin{array}{l}\text { Integrating Human Rights } \\
\text { Values in Regional Legal } \\
\text { Products in the social } \\
\text { sector/containing policies on: }\end{array}$ & Perda 12014 \\
\hline \multirow{4}{*}{$\begin{array}{l}\text { A. Availability } \\
\text { Everyone has the } \\
\text { right to social } \\
\text { security, } \\
\text { including } \\
\text { insurance. The } \\
\text { government is } \\
\text { obliged to } \\
\text { provide facilities } \\
\text { and } \\
\text { infrastructure to } \\
\text { fulfill these social } \\
\text { rights }\end{array}$} & $\begin{array}{l}\text { Provision of social security, } \\
\text { rehabilitation, } \\
\text { empowerment, } \\
\text { protection programs. }\end{array}$ & Article 7 , Article 10 \\
\hline & $\begin{array}{l}\text { Provision of social } \\
\text { institutions, rehabilitation, } \\
\text { education, training, and } \\
\text { welfare centers, as well as } \\
\text { shelter and social protection } \\
\text { houses. }\end{array}$ & Article 8 \\
\hline & $\begin{array}{l}\text { The provision of poverty } \\
\text { reduction programs, } \\
\text { including a) self-potential } \\
\text { development, b) food and } \\
\text { clothing assistance, c) } \\
\text { housing services, d) health } \\
\text { services, e) educational } \\
\text { services, f) access to } \\
\text { employment and business } \\
\text { opportunities, g) legal aid, } \\
\text { and/or h) social services. }\end{array}$ & Article 8 \\
\hline & $\begin{array}{l}\text { Provision of government } \\
\text { units/agencies that handle } \\
\text { social assistance and }\end{array}$ & $\begin{array}{l}\text { Article } 8 \text { Paragraph } \\
\text { (2) to Paragraph (6), } \\
\text { Article } 9 \text { Paragraph }\end{array}$ \\
\hline
\end{tabular}




\begin{tabular}{|c|c|c|}
\hline & security. & $\begin{array}{l}\text { (3), Article } 10 \\
\text { Paragraph } \quad(5), \\
\text { Article } 12 \text { Paragraph } \\
\text { (2), Article 16, Article } \\
\text { 18 Paragraph (3) }\end{array}$ \\
\hline & $\begin{array}{l}\text { Provision of quality human } \\
\text { resources in the social } \\
\text { welfare field, including } \\
\text { social welfare and } \\
\text { professional workers, social } \\
\text { volunteers, and social } \\
\text { instructors. }\end{array}$ & Article 8 , Article 10 \\
\hline & $\begin{array}{l}\text { Budget allocation for the } \\
\text { implementation of social } \\
\text { welfare. }\end{array}$ & Article 20 \\
\hline \multirow{2}{*}{$\begin{array}{l}\text { B. Accessibility } \\
\text { 1) Economic Access } \\
\text { Fulfillment of } \\
\text { economically } \\
\text { affordable social } \\
\text { rights for low-income } \\
\text { people }\end{array}$} & $\begin{array}{l}\text { Distribution of aid to the } \\
\text { poor, abandoned children, } \\
\text { and other vulnerable } \\
\text { groups. }\end{array}$ & $\begin{array}{l}\text { Article } 10 \text { paragraph } \\
\text { (1) }\end{array}$ \\
\hline & $\begin{array}{l}\text { Assisting the businesses of } \\
\text { the poor, including the ease } \\
\text { of licensing. }\end{array}$ & $\begin{array}{l}\text { Article } 8 \text { paragraph } \\
\text { (2) }\end{array}$ \\
\hline \multirow{4}{*}{$\begin{array}{l}\text { 2). Physical Access } \\
\text { Provision of access } \\
\text { for the fulfilling the } \\
\text { rights of vulnerable } \\
\text { groups }\end{array}$} & $\begin{array}{l}\text { Social welfare insurance for } \\
\text { the underprivileged. }\end{array}$ & - \\
\hline & Poverty reduction program. & Article 10 \\
\hline & $\begin{array}{l}\text { Social security program for } \\
\text { vulnerable groups. }\end{array}$ & Article 10 \\
\hline & $\begin{array}{l}\text { Provision of empowerment } \\
\text { and skill improvement } \\
\text { programs for vulnerable } \\
\text { groups/people with social } \\
\text { problems. }\end{array}$ & $\begin{array}{c}\text { Article } 8 \text { paragraph } \\
\text { (10) }\end{array}$ \\
\hline \multirow{2}{*}{$\begin{array}{l}\text { 3). Access to } \\
\text { information and } \\
\text { public participation } \\
\text { Everyone has the } \\
\text { right to seek, obtain, } \\
\text { own, store, process, } \\
\text { and convey }\end{array}$} & $\begin{array}{l}\text { Provision of opportunities } \\
\text { for the community to play a } \\
\text { role in implementing social } \\
\text { welfare. }\end{array}$ & Article 18 \\
\hline & $\begin{array}{l}\text { Provision of community } \\
\text { roles in organizing and } \\
\text { supervising the handling of }\end{array}$ & Article 18 \\
\hline
\end{tabular}




\begin{tabular}{|c|c|c|}
\hline \multirow{3}{*}{$\begin{array}{l}\text { information by using } \\
\text { all available means to } \\
\text { fulfill their social } \\
\text { rights }\end{array}$} & persons with social welfare. & \\
\hline & $\begin{array}{l}\text { Participation of the } \\
\text { community (including } \\
\text { vulnerable groups) in the } \\
\text { formulation, } \\
\text { implementation, and } \\
\text { supervision of policies } \\
\text { related to social issues. }\end{array}$ & Article 15, Article 18 \\
\hline & $\begin{array}{l}\text { Participation of the } \\
\text { community in supervising } \\
\text { the activities of actors in } \\
\text { implementing social } \\
\text { welfare. }\end{array}$ & - \\
\hline \multirow{5}{*}{$\begin{array}{l}\text { C. Obligation to } \\
\qquad \text { Respect } \\
\text { The government } \\
\text { allows the } \\
\text { community to fulfill } \\
\text { their social rights } \\
\text { independently by } \\
\text { respecting religious, } \\
\text { cultural, and } \\
\text { customary values }\end{array}$} & $\begin{array}{l}\text { Allowing the community to } \\
\text { organize social welfare, } \\
\text { including the formation of } \\
\text { associations. }\end{array}$ & $\begin{array}{c}\text { Article } 18 \text { paragraph } \\
(2)\end{array}$ \\
\hline & $\begin{array}{l}\text { Provision of encouragement } \\
\text { and facilities for the } \\
\text { community and business } \\
\text { world to implement social } \\
\text { responsibility. }\end{array}$ & Article 19 \\
\hline & $\begin{array}{l}\text { Increasing institutional } \\
\text { capacity and human } \\
\text { resources in the social } \\
\text { welfare field. }\end{array}$ & - \\
\hline & $\begin{array}{l}\text { Preserving heroism, } \\
\text { pioneering, and solidarity } \\
\text { values. }\end{array}$ & - \\
\hline & $\begin{array}{l}\text { Allowing the community to } \\
\text { provide financial support } \\
\text { for social welfare. }\end{array}$ & $\begin{array}{l}\text { Article } 18 \text { paragraph } \\
\text { (1) letter c }\end{array}$ \\
\hline \multirow[t]{3}{*}{$\begin{array}{l}\text { D. Obligation to } \\
\text { Protect }\end{array}$} & $\begin{array}{l}\text { Preventing and handling } \\
\text { social impacts on society. }\end{array}$ & Article 1 number 1 \\
\hline & $\begin{array}{l}\text { Social rehabilitation for } \\
\text { people who experience } \\
\text { social dysfunction. }\end{array}$ & Article 10 \\
\hline & $\begin{array}{l}\text { Provision of social } \\
\text { protection for vulnerable } \\
\text { people, such as assistance, } \\
\text { advocates, and legal aid. }\end{array}$ & Article 10 \\
\hline
\end{tabular}


Problems in regional legal products, especially regulations that are suspected of containing human rights violations, should be dealt with using a more serious mechanism as well. Since regional autonomy was implemented, problematic regional regulations have grown worse than ever before. As a result, services were not excellent, illegal levies (extortion) occur, and corruption was commonplace. Other problems also involved regional income during autonomy era. ${ }^{28}$ Therefore, the central government took the initiative to solve this problem by canceling problematic regional regulations throughout Indonesia. ${ }^{29}$ This initiative was considered important to maintain supremacy of law $^{30}$ and central government function to control local goverments. ${ }^{31}$

Generally, concepts, theories, and international conventions show that upholding the human rights of abandoned people, including the homeless and beggars, is the government's responsibility. Therefore, this problem is normatively charged to the government as the holder of the state's constitution mandate. The state has always been the stronger party because it possesses

28 Maria Rosarie Harni Triastuti, 'Optimalisasi Pendapatan Daerah Di Era Otonomi Dan Munculnya Perda-Perda Bermasalah [Optimizing Regional Revenue in the Era of Autonomy and the Emergence of Troubled Regional Regulations]', Jurnal $\begin{array}{llllll}\text { Administrasi Publik } & \text { 5, 2008), }\end{array}$ https://journal.unpar.ac.id/index.php/JAP/article/view/1565.

${ }^{29}$ Leo Agustino, 'Pembatalan 3.143 Peraturan Daerah: Satu Analisis Singkat [Cancellation of 3,143 Regional Regulations: One Brief Analysis]', CosmoGov: Jurnal Ilmu Pemerintahan 3, no. 1 (29 April 2017): 14-35, https:/ / doi.org/10.24198/cosmogov.v3i1.12405.

30 Aristo Evandy A. Barlian, 'Konsistensi Pembentukan Peraturan Daerah Berdasarkan Hierarki Perundang-Undangan Dalam Prespektif Politik Hukum [Consistency of the Formation of Regional Regulations Based on the Hierarchy of Legislation in the Perspective of Political Law]', Fiat Justisia: Jurnal Ilmu Hukum 10, no. 4 (2016): 605-22, https:// doi.org/10.25041/fiatjustisia.v10no4.801.

31 Ni'matul Huda, 'Pengawasan Pusat Terhadap Daerah (Kajian Terhadap Peraturan Daerah "Bermasalah") [Central Supervision of the Regions (Study of "Problematic" Regional Regulations)]', Jurnal Hukum IUS QUIA IUSTUM 10, no. 23 (2003): 28-45, https:/ / doi.org/10.20885/iustum.vol10.iss23.art2. 
authority and power, while the community is in a weaker position. This inherent authority and power in the state result in its placement as a holder of obligations. ${ }^{32}$

In the modern democratic concept approach, public policies should contain sparks of thoughts or opinions from state officials that represent the people, alongside equally reflect public opinions. ${ }^{33}$ Hence, every public policy must be oriented towards the people's interests. The formulation of government obligations was part of the effort to enforce economic and social rights, as well as emphasize the enforcement of civil and economic rights. ${ }^{34}$ This mean that everyone, including the homeless and beggars, was entitled to obtain and fulfill their basic human rights. Therefore, every policy and regulation in Perda 12014 should be fostered as part of the respect for universal human rights.

\section{Maqasid Syari'ah Perspective of Perda 12014}

The effectiveness of the Yogyakarta City Government Regional Regulation Number 1 of 2014 in overcoming the homeless and beggars was analyzed based on the Maqāșid ash-Syarīiah measurement. This sub-discussion describes the implementation of the regulation according to this concept:

32 Virgayani Fattah, 'Hak Asasi Manusia Sebagai Jus Cogens Dan Kaitannya Dengan Hak Atas Pendidikan [Human Rights as Juice Cogens and Its Relation to the Right to Education]', Yuridika 32, no. 2 (5 May 2017): 355-78, https:/ / doi.org/10.20473/ydk.v32i2.4775.

33 Andrea Louise Campbell, 'Policy Makes Mass Politics', Annual Review of Political Science 15 (8 March 2012): 333-51, https://doi.org/10.1146/annurev-polisci012610-135202; Matthew A. Baum and Philip B.K. Potter, 'The Relationships Between Mass Media, Public Opinion, and Foreign Policy: Toward a Theoretical Synthesis', Annual Review of Political Science 11 (7 November 2007): 39-65, https:// doi.org/10.1146/annurev.polisci.11.060406.214132.

34 Ifdhal Kasim and Johanes da Masenus Arus, Hak Ekonomi, Sosial, Budaya: EsaiEsai Pilihan: Buku 2 [Economic, Social, Cultural Rights: Selected Essays: Book 2] (Jakarta: Institute for Community Studies and Advocacy, 2001), 213-14. 


\section{The Implementation of Maqāșid ash-Syarī'ah in the Preventive Dimension}

Table of the research results of the Maqāṣid ash-Syarī'ah implementation in Regional Regulation Number 1 of 2014 concerning Countermeasures of the Homeless and Beggars based on Preventive Dimensions by the Yogyakarta Social Service

\begin{tabular}{|c|c|c|}
\hline $\begin{array}{c}\text { Maqā̄șid ash- } \\
\text { Syarī'ah Capacity } \\
\text { and Measurement }\end{array}$ & $\begin{array}{l}\text { Implementation of Regional } \\
\text { Regulation Number } 1 \text { of } 2014\end{array}$ & Result \\
\hline $\begin{array}{l}\text { Religious Guard } \\
\text { (hifz din) }\end{array}$ & $\begin{array}{l}\text { The implementation of social } \\
\text { service programs at } \\
\text { Assessment Camps, such as } \\
\text { studies (preaching) and joint } \\
\text { tadarus (recitation of the Al- } \\
\text { Quran in a group). Also, } \\
\text { equal rights to receive } \\
\text { training, availability of } \\
\text { prayer rooms, and praying in } \\
\text { rehabilitation homes to } \\
\text { prevent their return to their } \\
\text { homeless and begging } \\
\text { professions. }\end{array}$ & $\begin{array}{l}\text { The } \\
\text { implementation } \\
\text { of regional } \\
\text { regulations in } \\
\text { Assessment } \\
\text { Camps and } \\
\text { rehabilitation } \\
\text { homes has } \\
\text { complied with } \\
\text { the procedures } \\
\text { mandated by the } \\
\text { Homeless and } \\
\text { Beggars Regional } \\
\text { Regulation. }\end{array}$ \\
\hline $\begin{array}{c}\text { Soul Guard (hifz al } \\
\text { nafs) }\end{array}$ & $\begin{array}{l}\text { The implementation of the } \\
\text { regional regulation by the } \\
\text { Social Service involves } \\
\text { providing social assistance to } \\
\text { the homeless and beggars. } \\
\text { This includes basic needs } \\
\text { such as staple food, clothing, } \\
\text { temporary shelter, health } \\
\text { care, and medicines. Health } \\
\text { guidance from the Public } \\
\text { Health Center is conducted } \\
\text { once a week to impart }\end{array}$ & $\begin{array}{l}\text { The } \\
\text { implementation } \\
\text { of regional } \\
\text { regulations based } \\
\text { on the results } \\
\text { above shows that } \\
\text { some of the } \\
\text { obstacles } \\
\text { encountered } \\
\text { during } \\
\text { preventive the } \\
\text { efforts have been }\end{array}$ \\
\hline
\end{tabular}


Local Regulation on Homelessness and Beggars in Yogyakarta...

\begin{tabular}{|c|c|c|}
\hline & $\begin{array}{l}\text { knowledge about the } \\
\text { importance of maintaining } \\
\text { cleanliness and health. }\end{array}$ & $\begin{array}{l}\text { performed } \\
\text { according } \\
\text { procedures. }\end{array}$ \\
\hline $\begin{array}{l}\text { Mind guard (hifz al } \\
\text { 'aql) }\end{array}$ & $\begin{array}{l}\text { The program to maintain } \\
\text { common sense is realized by } \\
\text { administering activities to } \\
\text { homeless people and beggars } \\
\text { that enable them to think } \\
\text { creatively and have useful } \\
\text { skills for their future } \\
\text { provisions. }\end{array}$ & $\begin{array}{l}\text { The } \\
\text { implementation } \\
\text { corresponds with } \\
\text { the procedures } \\
\text { set by the } \\
\text { regulation. }\end{array}$ \\
\hline $\begin{array}{c}\text { Descendants } \\
\text { Guard (hifz al nasl) }\end{array}$ & $\begin{array}{l}\text { The regulation program is to } \\
\text { conduct outreach activities } \\
\text { for the homeless and beggars } \\
\text { by providing new insights to } \\
\text { motivate them to leave their } \\
\text { profession. }\end{array}$ & $\begin{array}{l}\text { The } \\
\text { implementation } \\
\text { is consistent with } \\
\text { the procedures } \\
\text { set by the } \\
\text { regulation. }\end{array}$ \\
\hline $\begin{array}{l}\text { Property Guard } \\
\text { (hifz al māl) }\end{array}$ & $\begin{array}{l}\text { The homeless and beggars } \\
\text { caught in raids will be } \\
\text { accommodated at Panti } \\
\text { Karya Assessment Camp, } \\
\text { Yogyakarta. They will } \\
\text { receive housing facilities } \\
\text { during the rehabilitation } \\
\text { period, including a room, } \\
\text { three meals a day, and two } \\
\text { isolation rooms. The isolation } \\
\text { room is specially meant for } \\
\text { inmates in emotionally } \\
\text { unfavorable conditions to } \\
\text { ensure they are unable to } \\
\text { hurt other inmates. }\end{array}$ & $\begin{array}{l}\text { The Social } \\
\text { Service program } \\
\text { has been } \\
\text { implemented } \\
\text { according to the } \\
\text { procedures } \\
\text { established by } \\
\text { the Regional } \\
\text { Regulation on } \\
\text { Countermeasures } \\
\text { of the Homeless } \\
\text { and Beggars. }\end{array}$ \\
\hline \multicolumn{3}{|c|}{$\begin{array}{l}\text { Preventive Efforts Research Results: } \\
\text { The results above show some obstacles encountered in implementing } \\
\text { the preventive efforts for the homeless and beggars, and their lack of } \\
\text { enthusiasm requires innovations. }\end{array}$} \\
\hline
\end{tabular}




\section{The Implementation of Maqāșid ash-Syarī'ah in the Coercive Dimension}

Table of the research results of the Maqāsid ash-Syarī'ah implementation in Regional Regulation Number 1 of 2014 concerning Countermeasures of the Homeless and Beggars based on the Coercive Dimension by the Yogyakarta Social Service

\begin{tabular}{|c|c|c|}
\hline $\begin{array}{l}\text { Maqāsisid ash- } \\
\text { Syarī'ah } \\
\text { Capacity and } \\
\text { Measurement }\end{array}$ & $\begin{array}{l}\text { Implementation of Regional } \\
\text { Regulation Number } 1 \text { of } 2014\end{array}$ & Result \\
\hline $\begin{array}{l}\text { Religious Guard } \\
\quad \text { (hifz dīn) }\end{array}$ & $\begin{array}{l}\text { The implementation of the regional } \\
\text { regulations by the Yogyakarta Social } \\
\text { Service with the Civil Service Police } \\
\text { Unit involves enforcement. This is to } \\
\text { enforce the law and regulate the } \\
\text { homeless and beggars to create order. }\end{array}$ & $\begin{array}{l}\text { The program is } \\
\text { less than optimal } \\
\text { in raiding } \\
\text { homeless people } \\
\text { and beggars, } \\
\text { resulting in } \\
\text { frequent leaks. }\end{array}$ \\
\hline $\begin{array}{c}\text { Soul Guard (hifz } \\
\text { al nafs) }\end{array}$ & $\begin{array}{l}\text { Officers take proactive action in } \\
\text { outreach to areas where the homeless } \\
\text { and beggars live and operate. } \\
\text { Outreach is an initial contact and a } \\
\text { process of building trust with them. It } \\
\text { also protects them from unfavorable } \\
\text { situations and conditions and ensures } \\
\text { their safety. }\end{array}$ & $\begin{array}{l}\text { The } \\
\text { implementation is } \\
\text { consistent with } \\
\text { the procedures set } \\
\text { by the regulation. }\end{array}$ \\
\hline $\begin{array}{l}\text { Mind guard (hifz } \\
\text { al 'aql) }\end{array}$ & $\begin{array}{l}\text { This activity provides psychological } \\
\text { and mental guidance to change } \\
\text { mindsets, attitudes, and pro-social } \\
\text { actions, based on the standards of } \\
\text { legal and social norms that apply in } \\
\text { society. It is the most important part } \\
\text { of elevating their confidence and high } \\
\text { spirits. }\end{array}$ & $\begin{array}{l}\text { The } \\
\text { implementation is } \\
\text { according to the } \\
\text { procedures set by } \\
\text { the regulation. }\end{array}$ \\
\hline $\begin{array}{l}\text { Descendants } \\
\text { Guard (hifz al }\end{array}$ & $\begin{array}{l}\text { It incorporates targets into the } \\
\text { community to allow them to have }\end{array}$ & $\begin{array}{l}\text { The } \\
\text { implementation }\end{array}$ \\
\hline
\end{tabular}


Local Regulation on Homelessness and Beggars in Yogyakarta...

\begin{tabular}{|c|l|l|}
\hline nasl) & $\begin{array}{l}\text { reasonable and worthy positions and } \\
\text { roles as citizens. }\end{array}$ & $\begin{array}{l}\text { follows the } \\
\text { procedures set by } \\
\text { the regulation. }\end{array}$ \\
\hline $\begin{array}{c}\text { Property Guard } \\
\text { (hifz al māl) }\end{array}$ & $\begin{array}{l}\text { This activity educates the homeless } \\
\text { and beggars with work knowledge } \\
\text { and skills and forms the necessary } \\
\text { attitudes for target adjustment. }\end{array}$ & $\begin{array}{l}\text { The } \\
\text { implementation is } \\
\text { in accordance } \\
\text { with the } \\
\text { procedures set by } \\
\text { the regulation. }\end{array}$ \\
\hline
\end{tabular}

The Implementation of Maqāṣid ash-Syarī'ah in Social Rehabilitation Dimension

Table of research results from the Maqāṣid asy-Syarī'ah implementation in Regional Regulation Number 1 of 2014 concerning Countermeasures of the Homeless and Beggars based on the Social Rehabilitation dimension by the Yogyakarta Social Service

\begin{tabular}{|c|l|l|}
\hline $\begin{array}{c}\text { Maqüșid ash- } \\
\text { Syarí'ah } \\
\text { Capacity and } \\
\text { Measurement }\end{array}$ & \multicolumn{1}{|c|}{$\begin{array}{c}\text { Implementation of Regional } \\
\text { Regulation Number 1 of } 2014\end{array}$} & \multicolumn{1}{c|}{ Result } \\
\hline $\begin{array}{c}\text { Religious } \\
\text { ding) }\end{array}$ & $\begin{array}{l}\text { There are numerous homeless } \\
\text { people and beggars in the Social } \\
\text { Service. Meanwhile, these activities } \\
\text { include mental and spiritual } \\
\text { guidance, such as performing the } \\
\text { Maghrib prayer in congregations at } \\
\text { mosques and reading the Qur'an } \\
\text { under the guidance of a companion } \\
\text { officer. }\end{array}$ & $\begin{array}{l}\text { The } \\
\text { implementation } \\
\text { follows the } \\
\text { procedures set } \\
\text { by the } \\
\text { regulation. }\end{array}$ \\
\hline $\begin{array}{l}\text { Soul Guard } \\
\text { (hifz al nafs) }\end{array}$ & $\begin{array}{l}\text { Care and treatment for the homeless } \\
\text { and beggars are provided at the } \\
\text { Assessment Camp to guard, protect, } \\
\text { and encourage them to perform their } \\
\text { social functions. Generally, the }\end{array}$ & $\begin{array}{l}\text { The Assessment } \\
\text { Camp stated } \\
\text { difficulties due } \\
\text { to the lack of } \\
\text { understanding }\end{array}$ \\
\hline
\end{tabular}




\begin{tabular}{|c|c|c|}
\hline & $\begin{array}{l}\text { homeless and beggars come in sick, } \\
\text { hence the Empowerment Team's } \\
\text { new task is caring for them. The } \\
\text { homeless and beggars below five } \\
\text { years old also receive care and } \\
\text { treatment as long as their parents } \\
\text { attend training. }\end{array}$ & $\begin{array}{l}\text { of the } \\
\text { conditions by } \\
\text { psychological } \\
\text { experts. }\end{array}$ \\
\hline $\begin{array}{c}\text { Mind guard } \\
\text { (hifz al 'aql) }\end{array}$ & $\begin{array}{l}\text { The implementation involves } \\
\text { vocational training to provide skills } \\
\text { to homeless people and beggars and } \\
\text { enable them to live independently or } \\
\text { productively. }\end{array}$ & $\begin{array}{l}\text { The } \\
\text { implementation } \\
\text { is in accordance } \\
\text { with the } \\
\text { procedures set } \\
\text { by the } \\
\text { regulation. }\end{array}$ \\
\hline $\begin{array}{c}\text { Descendants } \\
\text { Guard (hifz al } \\
\text { nasl) }\end{array}$ & $\begin{array}{l}\text { The accessibility and social } \\
\text { assistance services are referred to } \\
\text { entail providing facilities for } \\
\text { homeless people and beggars to } \\
\text { realize equal rights and } \\
\text { opportunities in all aspects of life. } \\
\text { Also, those who experience social } \\
\text { shocks and vulnerabilities are aided. }\end{array}$ & $\begin{array}{l}\text { The } \\
\text { implementation } \\
\text { is consistent } \\
\text { with the } \\
\text { procedures set } \\
\text { by the } \\
\text { regulation. }\end{array}$ \\
\hline $\begin{array}{c}\text { Property } \\
\text { Guard (hifz al } \\
\text { māl) }\end{array}$ & $\begin{array}{l}\text { Follow-up guidance is an activity to } \\
\text { strengthen the independence of } \\
\text { homeless people and beggars after } \\
\text { receiving social rehabilitation } \\
\text { services. Those who feel able to } \\
\text { return to their origin are given } \\
\text { further guidance training to } \\
\text { determine their abilities and skills } \\
\text { and are sent home. }\end{array}$ & $\begin{array}{l}\text { Sweeping and } \\
\text { monitoring } \\
\text { were performed } \\
\text { in several places } \\
\text { by the Social } \\
\text { Service, } \\
\text { consisting of } \\
\text { rehabilitation } \\
\text { staff and social } \\
\text { workers, and } \\
\text { the Civil Service } \\
\text { Police Unit. } \\
\text { After being } \\
\text { accommodated }\end{array}$ \\
\hline
\end{tabular}




\begin{tabular}{|l|l|l|}
\hline & $\begin{array}{l}\text { and identified } \\
\text { by age, the } \\
\text { productive } \\
\text { homeless } \\
\text { persons and } \\
\text { beggars are } \\
\text { rehabilitated } \\
\text { and given free } \\
\text { non-formal } \\
\text { education and } \\
\text { facilities to } \\
\text { restore proper } \\
\text { social standing } \\
\text { and decent } \\
\text { work. }\end{array}$ \\
\hline
\end{tabular}

Based on the targets, social rehabilitation of the homeless and beggars is expected to help the healing process at various sites. This is because humans comprise a single component consisting of mental, physical, environmental, social, cultural aspects, and various other elements. Therefore, social rehabilitation is performed to restore damaged souls with certain targets according to the patient's physical and mental state.

The Implementation of Maqāșid ash-Syarī'ah in the Social Reintegration Dimension

Social reintegration is a process of readjustment of several different elements into one unit. It is a process of re-establishing new norms and values for adapting to homeless people and beggars in social environments. This effort includes various guidance.

Table of research results of the Maqāṣid ash-Syarī'ah implementation in Regional Regulation Number 1 of 2014 concerning 
Countermeasures of the homeless and beggars based on the dimensions of social reintegration by the Yogyakarta Social Service

\begin{tabular}{|c|c|c|}
\hline $\begin{array}{l}\text { Maqāșid ash- } \\
\text { Syarí'ah } \\
\text { Capacity and } \\
\text { Measurement }\end{array}$ & $\begin{array}{l}\text { Implementation of Regional } \\
\text { Regulation Number } 1 \text { of } 2014\end{array}$ & Result \\
\hline $\begin{array}{l}\text { Religious } \\
\text { Guard (hifz } \\
\text { din) }\end{array}$ & $\begin{array}{l}\text { The Social Service performs } \\
\text { resocialization guidance to prepare } \\
\text { the homeless and beggars to guard } \\
\text { and practice their religion in peace. }\end{array}$ & $\begin{array}{l}\text { The } \\
\text { implementation } \\
\text { of the Social } \\
\text { Service Program } \\
\text { is in accordance } \\
\text { with the } \\
\text { procedures set by } \\
\text { the regulation }\end{array}$ \\
\hline $\begin{array}{l}\text { Soul Guard } \\
\text { (hiftz al nafs) }\end{array}$ & $\begin{array}{l}\text { This guidance aims to enable } \\
\text { homeless people and beggars to } \\
\text { protect themselves from risks on } \\
\text { the streets and develop their } \\
\text { economy, as guaranteed by the } \\
\text { government. }\end{array}$ & $\begin{array}{l}\text { The } \\
\text { implementation } \\
\text { is in accordance } \\
\text { with the } \\
\text { procedures set by } \\
\text { the regulation. }\end{array}$ \\
\hline $\begin{array}{l}\text { Mind guard } \\
\text { (hifz al 'aql) }\end{array}$ & $\begin{array}{l}\text { The program aims to prepare the } \\
\text { homeless and beggars to develop } \\
\text { quality in the education field for } \\
\text { themselves and their future } \\
\text { generations. }\end{array}$ & $\begin{array}{l}\text { The } \\
\text { implementation } \\
\text { is consistent with } \\
\text { the procedures } \\
\text { set by the } \\
\text { regulation. }\end{array}$ \\
\hline $\begin{array}{l}\text { Descendants } \\
\text { Guard (hifz al } \\
\text { nasl) }\end{array}$ & $\begin{array}{l}\text { The guidance aims to prepare } \\
\text { homeless people and beggars that } \\
\text { are willing and able to socialize } \\
\text { and adapt to their families and } \\
\text { social environments to ensure they } \\
\text { can perform their social functions. }\end{array}$ & $\begin{array}{l}\text { The } \\
\text { implementation } \\
\text { is in accordance } \\
\text { with the } \\
\text { procedures set by } \\
\text { the regulation. }\end{array}$ \\
\hline $\begin{array}{c}\text { Property } \\
\text { Guard (hifz al }\end{array}$ & $\begin{array}{l}\text { The Social Service aims to ensure } \\
\text { the homeless and beggars are }\end{array}$ & $\begin{array}{l}\text { The } \\
\text { implementation }\end{array}$ \\
\hline
\end{tabular}


Local Regulation on Homelessness and Beggars in Yogyakarta...

\begin{tabular}{|l|l|l|}
\hline māl) & $\begin{array}{l}\text { willing and able to work properly } \\
\text { and correctly. }\end{array}$ & $\begin{array}{l}\text { is consistent with } \\
\text { the procedures } \\
\text { set by the } \\
\text { regulation. }\end{array}$ \\
\hline
\end{tabular}

The implementation of Maqāșid ash-Syarī'ah in a more specific scope, as an indicator of the effectiveness of the Yogyakarta Social Service regional regulations in achieving the associated goals and objectives, are according to Islamic principles. Therefore, each Maqāșid ash-Syarīah indicator, as the basis for assessing the implementation of the Social Service program, shows that the preventive, coercive, rehabilitation and social reintegration efforts agree with the principles of human benefit.

The objectives of Islamic law (Maqāṣid ash-Syarī'ah) regarding the effectiveness of the Yogyakarta Regional Regulation Number 1 of 2014 implementation ae described below:

Table of System Approach on the Implementation of Articles of Regional Regulations

\begin{tabular}{|l|c|l|l|l|}
\hline No & $\begin{array}{c}\text { Maqūșid ash- } \\
\text { Syarī'ah } \\
\text { Classification }\end{array}$ & $\begin{array}{c}\text { Articles in } \\
\text { Regional } \\
\text { Regulation } \\
\text { Number 1 of } \\
2014\end{array}$ & $\begin{array}{c}\text { Maqāșid } \\
\text { asy- } \\
\text { Syarī'ah }\end{array}$ & $\begin{array}{c}\text { Features of the } \\
\text { Maqāșid ash- } \\
\text { Syarī'ah System }\end{array}$ \\
\hline 1 & $\begin{array}{c}\text { Religious } \\
\text { Guard (hifz } \\
\text { din) }\end{array}$ & $\begin{array}{l}\text { Spiritual mental } \\
\text { guidance } \\
\text { (Article 10). }\end{array}$ & $\begin{array}{l}\text { maqāsid } \\
\text { al } \\
\text { 'ámmah }\end{array}$ & $\begin{array}{l}\text { Nature } \\
\text { Cognitive } \\
\text { Purposefulness }\end{array}$ \\
\hline 2 & $\begin{array}{c}\text { Soul Guard } \\
\text { (hifz al nafs) }\end{array}$ & $\begin{array}{l}\text { a) improvement } \\
\text { in health status } \\
\text { (article 8 letter } \\
\text { b), in cases of } \\
\text { mental } \\
\text { disorders, } \\
\text { psychiatric }\end{array}$ & $\begin{array}{l}\text { maqāsid } \\
\text { al } \\
\text { 'ámmah }\end{array}$ & $\begin{array}{c}\text { Openness } \\
\text { Purposefulness }\end{array}$ \\
\hline
\end{tabular}




\begin{tabular}{|c|c|c|c|c|}
\hline & & $\begin{array}{l}\text { rehabilitation is } \\
\text { performed, and } \\
\text { c) care and } \\
\text { treatment (article } \\
\text { 10). }\end{array}$ & & \\
\hline 3 & $\begin{array}{c}\text { Mind Guard } \\
\text { (hifz al 'aql) }\end{array}$ & $\begin{array}{l}\text { a) mental- } \\
\text { spiritual } \\
\text { guidance } \\
\text { (Article } 10 \text { letter } \\
\text { d), and b) } \\
\text { education } \\
\text { improvement } \\
\text { (article } 8 \text { letter } \\
\text { d). }\end{array}$ & $\begin{array}{l}\text { Maqāșid } \\
\text { asy- } \\
\text { Syarī'ah } \\
\text { 'Ammah }\end{array}$ & $\begin{array}{l}\text { Interrelated } \\
\text { Purposefulness }\end{array}$ \\
\hline 4 & $\begin{array}{c}\text { Descendants } \\
\text { Guard (hifz al } \\
\text { nasl) }\end{array}$ & $\begin{array}{l}\text { a) returning the } \\
\text { homeless and } \\
\text { beggars to a life } \\
\text { of dignity } \\
\text { (article } 3 \text { ), and b) } \\
\text { public outreach } \\
\text { and education } \\
\text { (article } 8 \text { letter } \mathrm{f} \text { ). }\end{array}$ & $\begin{array}{l}\text { Maqāșid } \\
\text { asy- } \\
\text { Syarī'ah } \\
\text { 'āmmah }\end{array}$ & $\begin{array}{l}\text { Interrelated } \\
\text { Purposefulness }\end{array}$ \\
\hline 5 & $\begin{array}{c}\text { Property } \\
\text { Guard (hifzz al } \\
\text { māl) }\end{array}$ & $\begin{array}{l}\text { Providing forms } \\
\text { of social } \\
\text { assistance } \\
\text { (article } 8 \text { ). }\end{array}$ & $\begin{array}{l}\text { Maqāșid } \\
\text { asy- } \\
\text { Syarī'ah } \\
\text { 'āmmah }\end{array}$ & $\begin{array}{l}\text { Nature Cognitive } \\
\text { Interrelated } \\
\text { Wholeness } \\
\text { Purposefulness }\end{array}$ \\
\hline
\end{tabular}

In performing ijtihad (a genuine effort) to manage various situations, the benefit must be made a top priority, as it is the main goal of the Shari'a (Maqāșid ash-syarī'ah). ${ }^{35}$ It is one of the main strategies of the Shari'a general principles (Maqāsid ammah) in various cases and conditions. Shari'a also has a concept of a level of flexibility that details the Qur'an in each of its explanations, provisions, and material. Therefore, it has a role in benefiting society, as other norms and values will not be fulfilled, supposing some parts are missing.

35 Amir Mu'allim and Yusdani, Konfigurasi Pemikiran Hukum Islam (Yogyakarta: UII Press, 2001), 134. 
Local Regulation on Homelessness and Beggars in Yogyakarta...

\section{CONCLUSION}

The role and function of the Social Service in countermeasures of the homeless and beggars in Yogyakarta have been procedurally fulfilled based on the Regional Regulation Number 1 of 2014 . However, most of the regulations on the Regional Government initiative listed in the Proledga are not accompanied by an inventory list of problems, the academic texts, and public participation, especially from NGO groups. These regional regulations are still like previous laws or regulations that were used as references or those in other places. Although the regulations that guarantee the fulfillment of these rights are consistent with standard operating procedures, the Regional Regulation Number 1 of 2014 concerning Countermeasures of the Homeless and Beggars does not fully reflect the principles of human rights. The implementation in the field uses a preventive, coercive, rehabilitation, and social reintegration approach.

Furthermore, the implementation and implications of government programs for homeless and beggars have realized Maqāsid Syarī'ah. This includes the maintenance of religion (hifz adDin) through support for religious activities and development at Assessment Camps, alongside reason (hifz al-' Aql) through access to education and changes in mental and economic patterns. Also, it has realized the maintenance of the soul (hifz an-Nās) through continuous access to health, alongside offspring (hifz an-Nasl) by safeguarding health and safety through access to mental education, which affects their children, and the maintenance of property (hifz alMàl) through social assistance and security.

\section{REFERENCES}

Agustino, Leo. 'Pembatalan 3.143 Peraturan Daerah: Satu Analisis Singkat [Cancellation of 3,143 Regional Regulations: One Brief Analysis]'. CosmoGov: Jurnal Ilmu Pemerintahan 3, no. 1 (29 
Ahmad Syafii Rahman \& Amir Mu'allim

April

2017):

14-35.

https:// doi.org/10.24198/cosmogov.v3i1.12405.

Akbar, M. Zain Yaumil, and Sulistyowati. 'Peran Pemerintah Kabupaten Brebes Dalam Menanggulangi Penyandang Masalah Kesejahteraan Sosial (PMKS) Pada Gelandangan Dan Pengemis (Studi Kasus Desa Grinting) [The Role of the Brebes Regency Government in Overcoming People with Social Welfare Problems on Homeless and Beggars (Case Study of Grinting Village)]'. Journal of Politic and Government Studies 8, no. 03 (2019): 201-10.

Baried. Interview with Chief of Section of Social Rehabilitation for Socially Impaired and Drug Victims, 12 February 2020.

Barlian, Aristo Evandy A. 'Konsistensi Pembentukan Peraturan Daerah Berdasarkan Hierarki Perundang-Undangan Dalam Prespektif Politik Hukum [Consistency of the Formation of Regional Regulations Based on the Hierarchy of Legislation in the Perspective of Political Law]'. Fiat Justisia: Jurnal Ilmu Hukum 10, no. 4 (2016): 605-22. https:// doi.org/10.25041/fiatjustisia.v10no4.801.

Baum, Matthew A., and Philip B.K. Potter. 'The Relationships Between Mass Media, Public Opinion, and Foreign Policy: Toward a Theoretical Synthesis'. Annual Review of Political Science $11 \quad$ (7 November 2007): 39-65. https:/ / doi.org/10.1146/annurev.polisci.11.060406.214132.

Campbell, Andrea Louise. 'Policy Makes Mass Politics'. Annual Review of Political Science 15 (8 March 2012): 333-51. https://doi.org/10.1146/annurev-polisci-012610-135202.

Dimyati, Khudzaifah, and Kelik Wardiono. 'Dinamika Pemikiran Hukum: Orientasi Dan Karateristik Pemikiran Expertise Hukum Indonesia [The Dynamics of Legal Thought: Orientation and Characteristics of Indonesian Legal Expertise Thought]'. Jurnal Ilmu Hukum 8, no. 2 (September 2005): 13351. 
Dobinson, Ian, and Francis Johns. 'Qualitative Legal Research'. In Research Methods for Law, edited by Mike McConville and Wing Hong Chui, 16-45. Edinburgh: Edinburgh University Press, 2007.

Fadri, Zainal. 'Upaya Penanggulangan Gelandangan Dan Pengemis (Gepeng) Sebagai Penyandang Masalah Kesejahteraan Sosial (PMKS) Di Yogyakarta [Efforts to Manage Homeless Peopel and Beggars as Social Welfare Problems in Yogyakarta]'. Komunitas 10, no. 1 (2019): $1-19$. https:// doi.org/10.20414/komunitas.v10i1.1070.

Fattah, Virgayani. 'Hak Asasi Manusia Sebagai Jus Cogens Dan Kaitannya Dengan Hak Atas Pendidikan [Human Rights as Juice Cogens and Its Relation to the Right to Education]'. Yuridika 32, no. 2 (5 May 2017): 355-78. https:// doi.org/10.20473/ydk.v32i2.4775.

Fitriana, Mia Kusuma. 'Peranan Politik Hukum Dalam Pembentukan Peraturan Perundang-Undangan Di Indonesia Sebagai Sarana Mewujudkan Tujuan Negara (Role of Politics in Creation of Laws and Regulations in Indonesia as the Means of Realizing the Country's Goal)'. Jurnal Legislasi Indonesia 12, no. 2 (2015): $1-27$.

Gubernur Daerah Istimewa Yogyakarta. Peraturan Daerah Daerah Istimewa Yogyakarta Nomor 1 Tahun 2014 Tentang Penanganan Gelandangan dan Pengemis (2014).

Huda, Ni'matul. 'Pengawasan Pusat Terhadap Daerah (Kajian Terhadap Peraturan Daerah "Bermasalah") [Central Supervision of the Regions (Study of "Problematic" Regional Regulations)]'. Jurnal Hukum IUS QUIA IUSTUM 10, no. 23 (2003):

28-45.

https:// doi.org/10.20885/iustum.vol10.iss23.art2.

Ismi. Interview with Office of Social Services, 13 February 2020.

Jannati, Mutiaratih Larasati, and Johannes Sutoyo. 'Hasil Dan Dampak Upaya Koersif Dalam Penegakan Peraturan Daerah 
Daerah Istimewa Yogyakarta Nomor 1 Tahun 2014 Tentang Penanganan Gelandangan Dan Pengemis [Results and Impact of Coercive Efforts in Enforcement of Yogyakarta Special Region Regulation Number 1 of 2014 Concerning Handling Homeless and Beggars]'. Jurnal Kriminologi Indonesia 13, no. 1 (2018).

http://journal.ui.ac.id/index.php/jki/article/view/9042.

Kasim, Ifdhal, and Johanes da Masenus Arus. Hak Ekonomi, Sosial, Budaya: Esai-Esai Pilihan: Buku 2 [Economic, Social, Cultural Rights: Selected Essays: Book 2]. Jakarta: Institute for Community Studies and Advocacy, 2001.

Kasim, Ifdhal, and Johanes da Masenus Arus. Hak Ekonomi Sosial Dan Budaya: Esai-Esai Pilihan. II. Jakarta: Lembaga Studi dan Advokasi Masyarakat, 2001.

Khairunnisa, Tiara, Eko Priyo Purnomo, and Lubna Salsabila. 'Smart Urban Service: Upaya Rehabilitasi dan Preventif Pengemis dan Gelandangan Kota Yogyakarta [Smart Urban Service: Rehabilitation and Preventive Efforts for Beggars and Homeless in Yogyakarta City]'. Moderat: Jurnal Ilmiah Ilmu Pemerintahan 6, no. 1 (2020): 29-42. https:// doi.org/10.25157/moderat.v6i1.3156.

Khakim, Mufti, and Egi Purnomo Aji. 'Penegakkan Hukum Peraturan Daerah Nomor 01 Tahun 2014 Tentang Penanganan Gelandangan Dan Pengemis Daerah Istimewa Yogyakarta [Law Enforcement of Regional Regulations Number 01 of 2014 Concerning the Handling of Homeless and Beggars in the Special Region of Yogyakarta]'. Jurnal Citizenship: Media Publikasi Pendidikan Pancasila Dan Kewarganegaraan 4, no. 1 (2021):

26-37.

https:// doi.org/10.12928/citizenship.v4i1.19906.

Mawaza, Jayyidan Falakhi, and Zaenuddin. 'Dilema Kebijakan Penanganan Gelandangan dan Pengemis di Yogyakarta (Studi Kasus Perda DIY No. 1 Tahun 2014) [Policy Dilemma for Handling Homeless People and Beggers in Yogyakarta (Case 
Local Regulation on Homelessness and Beggars in Yogyakarta...

Study of Perda No. 1 Year 2014)]'. Spirit Publik: Jurnal Administrasi Publik 15, no. 2 (2020): 131-45. https:// doi.org/10.20961/sp.v15i2.39754.

Mu'allim, Amir and Yusdani. Konfigurasi Pemikiran Hukum Islam. Yogyakarta: UII Press, 2001.

Niswati, Khurri. 'Faktor-Faktor Yang Mempengaruhi Kemiskinan Di Daerah Istimewa Yogyakarta Tahun 2003-2011 [Factors Affecting Poverty in the Special Region of Yogyakarta in 20032011]'. Eko-Regional: Jurnal Pembangunan Ekonomi Wilayah 9, no.

https:// doi.org/10.20884/1.erjpe.2014.9.1.480.

Putri, Novie Purnia, and Munifatuz Zahro'. 'Pemberdayaan Gelandangan Dan Pengemis Melalui Bimbingan Vokasi Di Balai Rehabilitasi Unit Bina Karya Yogyakarta [Empowerment of Homeless Households and Beggers Through Vocational Guidance at the Rehabilitation Center of the Bina Karya Unit, Yogyakarta]'. EMPATI: Jurnal Ilmu Kesejahteraan Sosial 9, no. 1 (2020): 48-58. https:/ / doi.org/10.15408/empati.v9i1.16481.

Raudah, Siti. 'Implementasi Peraturan Daerah Nomor 17 Tahun 2015 Tentang Penanggulangan Masalah Gelandangan Dan Pengemis (Gepeng) (Ttudy Kasus Di Kecamatan Amuntai Tengah Kabupaten Hulu Sungai Utara) [Implementation of Regional Regulation Number 17 Year 2015 on Efforts to Overcome Problems of Homeless and Beggars (Case Study in Amuntai Tengah Sub-District Hulu Sungai Utara)]'. Jurnal PubBis 3, no. 1 (2019): 10-19.

Saragih, Juli Panglima. 'Faktor Penyebab Dan Kebijakan Pemerintah Provinsi Daerah Istimewa Yogyakarta Menghapus Kemiskinan [Causes of Poverty and Yogyakarta Government Policy for Eradicating Poverty]'. Jurnal Ekonomi Dan Studi Pembangunan 6, no. 2 (2014): 139-55.

Sari, Novita Ika. 'Determinan Tingkat Kemiskinan Di Daerah Istimewa Yogyakarta Tahun 2007 - 2014 [Determinants of 
Poverty Levels in the Special Region of Yogyakarta in 2007 2014]'. Economics Development Analysis Journal 7, no. 2 (2018): 128-36. https:// doi.org/10.15294/edaj.v8i2.23411.

Setiawan, Hendy. 'Fenomena Gelandangan Pengemis Sebagai Dampak Disparitas Pembangunan Kawasan Urban dan Rural di Daerah Istimewa Yogyakarta [The Phenomenon of Homeless Beggars as the Impact of Disparity in Urban and Rural Development in Yogyakarta Special Province]'. Moderat: Jurnal Ilmiah Ilmu Pemerintahan 6, no. 2 (2020): 361-75. https:// doi.org/10.25157/moderat.v6i2.3218.

Suhardjana, Johannes. 'Supremasi Konstitusi Adalah Tujuan Negara [The Supremacy of the Constitution Is the Goal of the State]'. Jurnal Dinamika Hukum 10, no. 3 (2010): 253-64. https:// doi.org/10.20884/1.jdh.2010.10.3.96.

Triastuti, Maria Rosarie Harni. 'Optimalisasi Pendapatan Daerah Di Era Otonomi Dan Munculnya Perda-Perda Bermasalah [Optimizing Regional Revenue in the Era of Autonomy and the Emergence of Troubled Regional Regulations]'. Jurnal Administrasi Publik 5, no. 2 (2008). https://journal.unpar.ac.id/index.php/JAP/article/view/15 65.

Webley, Lisa. 'Qualitative Approaches to Empirical Legal Research'. In The Oxford Handbook of Empirical Legal Research, edited by Peter Cane and Herbert M. Kritzer, 927-51. Oxford: Oxford University Press, 2010. https://doi.org/10.1093/oxfordhb/9780199542475.013.0039. 